\title{
ENVIRONMENTAL BENEFITS OF CATCH CROPS CULTIVATION
}

\begin{abstract}
The role of catch crops in modern agriculture has increased in recent years. In addition to a production of animal feed, they have a positive impact on quality of soil. This study determined the suitability of selected stubble catch crops (white mustard, lacy phacelia, and a mixture of faba bean + spring vetch) to improve production, economic and energy effects of spring wheat grown in 3-year monoculture relative to the control treatment (without catch crops). Two tillage systems were used: conventional tillage and no-tillage (conservation tillage). A field study was conducted over the period 2014-2016 at the Czeslawice Experimental Farm, Lubelskie Voivodeship, Poland. The study proved the high suitability of catch crops to increase the spring wheat yields (under both tillage systems). Regardless of the catch crops, the productivity of wheat was higher under conventional tillage. The catch crops (in particular white mustard) and the conservation tillage system contributed to an improved energy efficiency index of production. The white mustard catch crop also had the most beneficial effect on the economic profitability of spring wheat production. This was due to the low cost of cultivation of this catch crop and its beneficial impact on obtaining high yields of spring wheat.
\end{abstract}

Keywords: catch crops, tillage system, spring wheat, productivity, economic efficiency index, energy efficiency index

\section{Introduction}

Due to the high proportion of cereals in the crop structure in Poland and across the world as well as the need to grow them after other grain crops or in monoculture, the research on mitigation of the negative effects of such stands on crop productivity continues to be topical. Therefore, growing catch crops, which perform phytosanitary functions, support mineral fertilisation, and improve the balance of organic matter and nutrients in soil, is highly important [1-3]. Ploughing in of the biomass of catch crops or leaving it in the field as mulch positively affects the productivity of cereal crops sown after them, while using low inputs at the same time. This particularly relates to Brassica species, such as white mustard, black mustard, oilseed rape, and oil radish [4, 5]. The impact strength of a catch crop depends on its type and selection of crop species. Under good soil conditions and in humid habitats, cultivation of a white mustard catch crop increases the yields of spring cereals by $8-10 \%$ [6]. The productivity and consequential effect (including the

\footnotetext{
${ }^{1}$ Faculty of Environmental Engineering, Lublin University of Technology, ul. Nadbystrzycka 40B, 20-618 Lublin, Poland, ORCID: LP 0000-0003-0628-6735, WC 0000-0002-8682-8428, JK 0000-0002-4809-2472

${ }^{2}$ Department of Herbology and Plant Cultivation Techniques, University of Life Sciences, ul. Akademicka 13, 20-950 Lublin, Poland, ORCID: CK 0000-0001-5759-8320; EH 0000-0002-7893-7958

*Corresponding author: 1.pawlowski@pollub.pl
} 
economic one) of catch cropping depend, among others, on habitat conditions (weather and soil conditions) and hence it is advisable to determine which species are best adapted to a specific region of a given country.

Soil tillage is an energy- and labour-consuming element of agronomic practices. It is estimated that it consumes, depending on the crop species and soil conditions, from $30 \%$ to $60 \%$ of the total amount of fuel used in production. On account of this high labour and energy consumption of tillage, the agricultural practice continually seeks various modifications and methods to reduce the inputs on soil tillage. The so-called conservation tillage, which consists in keeping the soil surface under plant cover formed by catch crops or crop residue mixed with the topsoil for as long as possible, has lately become increasingly widespread [7-9]. The main assumption of this tillage system is to leave crop residue or catch crops as mulch on the soil surface, even over the winter period, which provides the protection against erosion, reduced water evaporation, increased biological activity of the soil and its inhabitation by diverse soil fauna. Another very important aspect of such tillage is the replacement of ploughing with the implements that do not turn the soil over, such as rigid tine cultivators, rotary or disk harrows, different cultivator drills, and special direct drills. Owing to conservation tillage, it is possible to reduce the soil nitrogen losses resulting from leaching of nitrates, because standing catch crops take them up from the soil until late autumn. Apart from that, reduced tillage improves the economic and energy effects of crop production [10-13].

This study hypothesized that the use of the phytosanitary and allelopathic effects of catch crops in combination with conservation tillage would compensate for the negative impacts of the spring wheat cultivation under several years of monoculture, enhancing its productivity (in terms of yield quantity as well as economic and energy efficiency). Apart from the natural effects, the possibility of receiving payments by farmers under the EU's agri-environmental schemes will also contribute to this.

The aim of this study was to determine the effects of selected catch crop species on the productivity of spring wheat as well as on the economic and energy efficiency of cereal production under loess soil conditions in the Lublin region, Poland. Moreover, this research analysed to what extent the use of reduced tillage (no-tillage) would affect the above-mentioned characteristics, compared to the conventional tillage system.

\section{Material and methods}

A field experiment on monoculture cultivation of spring wheat was established in 2013, whereas the research results included in this work were collected over the period of 2014-2016 (three-year monoculture). The experiment was established at the Czeslawice Experimental Farm, belonging to the University of Life Sciences in Lublin (Poland), on the loess soil with the grain size distribution of silt loam (PWsp) and categorised as good wheat soil complex (soil class II). In the year in which the experiment was set up, the soil humus content was $1.44 \%, \mathrm{pH}=6.2$, while the $\mathrm{P}, \mathrm{K}$ and $\mathrm{Mg}$ content was, 160, 284, and $64 \mathrm{mg} \mathrm{kg}^{-1}$ soil, respectively. The experiment was set up as a split-plot design with five replicates in plots with an area of $27 \mathrm{~m}^{2}$. The design of the experiment comprised two factors: I. Type of catch crop in a spring wheat monoculture: A - control treatment (without catch crops); B - white mustard (varietas 'Borowska'); C - lacy phacelia (varietas 'Stala'); D - faba bean + spring vetch (varietas 'Amulet' + varietas 'Hanka'). II. Tillage practices used after the catch crops were harvested and before harvest of the cereal crop: 
1. conventional tillage - after harvest of the catch crops (October), their biomass was shredded and ploughed under during autumn ploughing, whereas in spring the soil was prepared using a seedbed cultivator, mineral fertilisers were subsequently applied, and finally spring wheat was sown using a seed drill. 2. conservation tillage (no-tillage) - after the catch crops were harvested in October, their biomass was left in the field as mulch until $15^{\text {th }}$ March; in spring, this mulch was ploughed under with a disk harrow, the field was smoothed using a spike tooth harrow, mineral NPK fertilisers were subsequently applied, and spring wheat was sown with a seed drill.

During the experimental years, spring wheat was sown at the optimal agronomic time for the region (the first/second decade of April). In all treatments, mineral NPK fertilisation was applied (adjusted to the requirements of the individual catch crop species), and subsequently the catch crops were sown.

Based on the availability of the major macronutrients in the soil used in the experiment and taking into account "economical" crop protection to be used, the following rates of mineral fertilisers $\left[\mathrm{kg} \mathrm{ha}^{-1}\right]$ were applied for the individual crops included in the field experiment: spring wheat $\left(\mathrm{N}-60, \mathrm{P}_{2} \mathrm{O}_{5}-50, \mathrm{~K}_{2} \mathrm{O}-80\right)$, white mustard ( $\left.\mathrm{N}-40\right)$, lacy phacelia $(\mathrm{N}-40)$, faba bean + spring vetch $(\mathrm{N}-20)$. The sowing of the catch crops was carried out in the second decade of August in each year. The seeding rate was as follows, respectively: white mustard - $20 \mathrm{~kg} \mathrm{ha}^{-1}$, lacy phacelia $-5 \mathrm{~kg} \mathrm{ha}^{-1}$, faba bean + spring vetch $-(100+40) \mathrm{kg} \mathrm{ha}^{-1}$. Spring wheat, on the other hand, was seeded (at a rate of $200 \mathrm{~kg} \mathrm{ha}^{-1}$ ) in the second decade of April.

The spring wheat seeds were dressed with Raxil $060 \mathrm{FS}$ at a rate of $50 \mathrm{~mL} / 100 \mathrm{~kg}$ seed. The other crop protection products were used at the lower limits of the recommended rates (in accordance with the "economical" crop protection strategy adopted in the experiment) and they were as follows:

- herbicide - Sekator 6,25 WG (amidosulfuron + iodosulfuron-methyl-sodium + mefenpyr-diethyl) - $0.2 \mathrm{~kg} \mathrm{ha}^{-1}$ (at tillering stage - BBCH 27-28);

- $\quad$ fungicide - Alert $375 \mathrm{SC}$ (flusilazole + carbendazim) - $0.9 \mathrm{~L} \mathrm{ha}^{-1}$ (at stem elongation $\mathrm{BBCH} 31-32$ );

- growth retardant - Stabilan $750 \mathrm{SL}$ (chlormequat chloride) - $0.9 \mathrm{~L} \mathrm{ha}^{-1}$ (from the 1 st node stage until the flag leaf just visible stage - BBCH 31-37).

After the wheat was harvested (in the first decade of August) and the grain was dried, grain yield was determined for each treatment and expressed in $1000 \mathrm{~kg} \mathrm{ha}^{-1}$.

The economic evaluation (gross margin) and energy evaluation (energy efficiency index) were the final stage of the analysis investigating the effects of individual tillage systems and stubble catch crops on the productivity of spring wheat (grain yield). The calculations were made in the prices from the last full year of the study (2016) based on 2016 market prices and prices for the following items were used in the calculations [€]: wheat grain, seed material (spring wheat, white mustard, lacy phacelia, faba bean, spring vetch), crop protection products (seed dressing Raxil 06 FS; Sekator 6,25 WG; Stabilan 750 SL; Alert 375 S.C. [ $€ \mathrm{~L}^{-1}$ ], and mineral fertilisers ( $\mathrm{N}$ - ammonium nitrate $34 \%$, $\mathrm{P}$ - granulated triple superphosphate $46 \%, \mathrm{~K}$ - potassium salt $50 \%$ [€/100 kg]. Gross margin is the value of annual output per hectare of crop minus the direct costs incurred to produce this output. The calculation of the gross margin also included the changes in the system of cover crop payments (74.4-100.0 $€ \mathrm{ha}^{-1}$, depending on the crop grown) under the agri-environmental scheme of the Rural Development Programme (RDP). 


\section{Calculations of economic and energy efficiency and statistical analysis}

The energy efficiency index of crop production is the ratio of the amount of energy contained in yields to energy inputs. It was calculated by using the ratio of the yield energy value to the inputs and multiplying the derived value by 100 :

$$
E_{e}=\frac{P_{e}}{N_{e}}
$$

where: $E_{e}$ - energy efficiency index [-]; $P_{e}$ - yield energy value per ha $[\mathrm{MJ}] ; N_{e}$ - energy inputs used to produce output (yield) per ha $[\mathrm{MJ}]$.

The energy inputs included four streams of energy: direct energy carriers (fuel, lubricants), raw materials and materials (fertilisers, seeds, crop protection products), capital expenditures (wear and tear of machines and implements during operation as well as spare parts and machines that needed repair), and human labour inputs. The energy evaluation included the grain yields (the average for 2014-2016), the energy value of which was determined following the methodology recommended by FAO. This method assumes that $1 \mathrm{~kg}$ of the dry weight of the main yield (grain) has a value of $18.36 \mathrm{MJ}$. On the other hand, the labour inputs (human labour and tractors) were determined based on the agronomic practices used in the experiment, taking into account the selection of machines and types of operations as well as using the available normative standards $[14,15]$.

The inputs associated with the consumption of energy carriers were calculated by using the following rates:

- mineral fertilisers:

$\begin{array}{ll}\text { nitrogen }(\mathrm{N}) & 70 \mathrm{MJ} \mathrm{kg}^{-1} \\ \text { phosphorus }(\mathrm{P}) & 14 \mathrm{MJ}_{\mathrm{kg}}^{-1} \\ \text { potassium }(\mathrm{K}) & 10 \mathrm{MJ} \mathrm{kg} \\ \text { ds of cereals and legumes } & 7.5 \mathrm{MJ} \mathrm{kg} \\ \text { ds of grasses and small-seeded plants } & 30 \mathrm{MJ} \mathrm{kg} \\ \text { p protection products (active ingredient) } & 300 \mathrm{MJ} \mathrm{kg}^{-1} \\ \text { sel fuel } & 48 \mathrm{MJ} \mathrm{kg} \\ \text { ar and tear of tractors and agricultural machines } & 112 \mathrm{MJ} \mathrm{kg}^{-1} \\ \text { re parts } & 80 \mathrm{MJ} \mathrm{kg} \\ \text { air materials } & 30 \mathrm{MJ} \mathrm{kg}^{-1} \\ \text { ricants } & 22 \mathrm{MJ} \mathrm{kg}^{-1} \\ \text { man labour } & 40 \mathrm{MJ} \mathrm{kg}{ }^{-1}\end{array}$

The actually used production inputs (machines, seeds, crop protection products) and the determined human labour inputs were converted into MJ. To this end, the relevant energy consumption indices and the ratios used in the energy calculation for crop production were applied.

Analysis of variance (ANOVA) was used to statistically analyse the results by employing Statistica PL 13.3, while Tukey's test was applied to determine the HSD (Honest Significant Difference) values at $p<0.05$.

\section{Results and discussion}

The spring wheat grain yield was significantly modified by both experimental factors (Table 1). Conservation tillage caused a decrease in grain yield, on average by $0.26 \mathrm{tha}^{-1}$ (6\%), relative to conventional tillage. The catch crops had an impact on the increased 
productivity of spring wheat, but the cultivation of white mustard contributed to a significantly higher grain yield compared to the control treatment (a $15 \%$ increase in yield) and lacy phacelia (by $9 \%$ ). The legume mixture affected an increase in grain yield by about $5 \%$. Significantly the lowest grain yield $\left(3.99 \mathrm{t} \mathrm{ha}^{-1}\right)$ was found in the control treatment (without catch crops) under conservation tillage (no-tillage). On the other hand, significantly the highest grain yield $\left(5.02 \mathrm{t} \mathrm{ha}^{-1}\right)$ was harvested from the fields sown with the white mustard stubble crop ploughed in in autumn (conventional tillage).

Grain yield of spring wheat [tonne ha ${ }^{-1}$ ] (on average over the study period)

\begin{tabular}{|c|c|c|c|}
\hline \multirow{2}{*}{ Stubble catch crop } & \multicolumn{3}{|c|}{ Tillage system } \\
\hline & Conventional & Conservation & Mean \\
\hline without catch crop & 4.32 & 3.99 & 4.15 \\
\hline white mustard & 5.02 & 4.69 & 4.85 \\
\hline lacy phacelia & 4.62 & 4.48 & 4.55 \\
\hline faba bean + spring vetch & 4.52 & 4.27 & 4.39 \\
\hline Mean & 4.62 & 4.36 & - \\
\hline $\begin{array}{l}\text { HSD }(0.05): \\
\text { tillage system }(a)=0.256 \\
\text { catch crop }(b)=0.312 \\
\text { interaction }(a \times b)=0.274\end{array}$ & & & \\
\hline
\end{tabular}

Some experiments on tillage reductions prove that generally, a decrease in yields of spring wheat and other cereals from 8 to $15 \%$ is recorded under no-tillage in comparison with conventional tillage. Higher grain yield under conventional tillage predominantly results from a higher ear density and grain weight per ear, relative to conservation tillage treatments [16]. These observations were partially confirmed by the results of the present study (Tables 2 and 3).

Number of years of spring wheat per $1 \mathrm{~m}^{2}$ before harvest (on average over the study period)

\begin{tabular}{|c|c|c|c|}
\hline \multirow{2}{*}{ Stubble catch crop } & \multicolumn{3}{|c|}{ Tillage system } \\
\cline { 2 - 4 } & Conventional & Conservation & Mean \\
\hline without catch crop & 398 & 394 & 396 \\
\hline white mustard & 438 & 425 & 431 \\
\hline lacy phacelia & 423 & 424 & 414 \\
\hline faba bean + spring vetch & 416 & 412 & - \\
\hline Mean & 419 & 414 & \\
\hline $\begin{array}{l}\text { HSD (0.05): } \\
\text { tillage system }(\mathrm{a})=\text { not significant } \\
\text { catch crop (b) }=17.9 \\
\text { interaction }(\mathrm{a} \times \mathrm{b})=\text { not significant }\end{array}$
\end{tabular}

When analysing the study results shown in Table 2, it can be noted that the tillage system did not have a statistically significant effect on ear density before spring wheat harvest. Under conventional tillage conditions, the average number of wheat ears per $1 \mathrm{~m}^{2}$ was higher by only 5 ears (1.2\%) compared to no-tillage (conservation tillage). The use of catch cropping in the spring wheat monoculture contributed to a significantly higher number of ear-bearing tillers per unit area compared to the control treatment, regardless of the tillage system. Growing white mustard had the most beneficial effect on the 
characteristic in question (an average increase of the number of ears per $1 \mathrm{~m}^{2}$ by 36 ears), followed by the cultivation of lacy phacelia (an increase by 27 ears) and the legume mixture (an increase by 18 ears).

Table 3

Grain weight per ear of spring wheat [g] (on average over the study period)

\begin{tabular}{|c|c|c|c|}
\hline \multirow{2}{*}{ Stubble catch crop } & \multicolumn{3}{|c|}{ Tillage system } \\
\hline & Conventional & Conservation & Mean \\
\hline without catch crop & 1.10 & 1.01 & 1.05 \\
\hline white mustard & 1.15 & 1.12 & 1.13 \\
\hline lacy phacelia & 1.11 & 1.09 & 1.10 \\
\hline faba bean + spring vetch & 1.12 & 1.08 & 1.10 \\
\hline Mean & 1.12 & 1.07 & - \\
\hline $\begin{array}{l}\text { HSD }(0.05): \\
\text { tillage system }(a)=0.049 \\
\text { catch crop }(b)=0.049 \\
\text { interaction }(a \times b)=0.059\end{array}$ & & & \\
\hline
\end{tabular}

Conservation tillage had a statistically significant effect on decreasing the grain weight per year on average by $0.05 \mathrm{~g}$, in comparison with the conventional system. However, all stubble crops contributed to a significant increase in grain weight per year, compared to the control treatment: white mustard by $7 \%$, while lacy phacelia and the legume mixture by $5 \%$, irrespective of the tillage system. The statistical analysis confirmed that the lowest grain weight per ear was obtained under control treatment conditions with no-tillage.

In a study by Vogler et al. [11], the long-term use of conservation tillage did not reduce the crop yields compared to conventional tillage.

Hansen et al. [1], Haramoto et al. [4] and Harasim et al. [5] reported that ploughing in of the biomass of Brassica or legume stubble crops as well as of successful undersown crops beneficially affects the productivity of spring wheat and spring barley. However, incorporation of mulch into the soil in spring, immediately before sowing spring cereals, has a smaller yield-increasing effect, which was confirmed by this study. Kwiatkowski et al. [6] and Wlodek et al. [17] proved that growing white mustard as a catch crop has the most beneficial effect on the productivity of spring wheat.

Kwiatkowski et al. [15] observed that the monoculture period affects the reduction in spring wheat yield (the so-called decline effect) to a greater extent than the tillage system, whereas catch crops efficiently mitigate the effects of growing a cereal crop after itself. The above-mentioned thesis is confirmed by the results of this research (Table 4).

The third year of the spring wheat monoculture had an effect on reducing the grain yield, on average by $17.4 \%$ under the control treatment conditions (without catch crops). Catch cropping caused the grain yield to be lower by only 7.9-9.3\% in the 3rd year of the monoculture than that recorded in its 1 st year (Table 4). The tillage system also influenced significantly the changes in the grain yield of spring wheat over the study period. In the 3rd year of the monoculture, relative to the 1st year, a lower loss in yield was recorded in the conventional tillage treatment $(10.1 \%)$, whereas under conservation tillage the decline in yield was $11.5 \%$. A significant interaction was found - the spring wheat grain yield was significantly the lowest (by $18.6 \%$ relative to the 1st year) in the no-tillage treatments without a catch crop.

Due to the large documentation material collected over the three-year study period and given the use of uniform agronomic practices and the same crop protection products during 
this period, the economic analysis (gross margin) was performed using the average yields of spring wheat for the period 2014-2016. During the study period, the prices of production inputs (seed material, mineral fertilisers, and crop protection chemicals) and grain fluctuated; therefore, the analysis was conducted in the prices from the last full year of the study.

Table 4

Changes in grain yield of spring wheat in the 3rd year of monoculture

(yield in the 1st year of monoculture $=100 \%$ )

\begin{tabular}{|c|c|c|c|}
\hline \multirow{2}{*}{ Stubble catch crop } & \multicolumn{3}{|c|}{ Tillage system } \\
\hline & Conventional & Conservation & Mean \\
\hline without catch crop & -16.2 & -18.6 & -17.4 \\
\hline white mustard & -7.2 & -8.6 & -7.9 \\
\hline lacy phacelia & -8.1 & -9.0 & -8.5 \\
\hline faba bean + spring vetch & -8.8 & -9.7 & -9.2 \\
\hline Mean & -10.1 & -11.5 & - \\
\hline $\begin{array}{l}\text { HSD }(0.05): \\
\text { tillage system }(a)=1.16 \\
\text { catch crop }(b)=1.23 \\
\text { interaction }(a \times b)=2.2\end{array}$ & & & \\
\hline
\end{tabular}

The tillage systems were not of major importance for the final economic effect of monoculture cropping of spring wheat, because the calculation of gross margin does not include the costs of fuel consumption, equipment depreciation, and human labour, but only the costs of seed material, crop protection products, and mineral fertilisers. The economic calculation also included direct payments for cover cropping that existed under the Rural Development Programme (RDP) 2014-2016.

Table 5

Direct costs incurred during the monoculture cultivation of spring wheat depending on the catch crop [€ ha $\left.{ }^{-1}\right]-$ on average over the study period

\begin{tabular}{|c|c|c|c|c|}
\hline \multirow{2}{*}{ Specification } & \multicolumn{4}{|c|}{ Direct costs } \\
\cline { 2 - 5 } & Seeds & $\begin{array}{c}\text { Crop protection } \\
\text { products }\end{array}$ & $\begin{array}{c}\text { Mineral } \\
\text { fertilisers }\end{array}$ & Total \\
\hline Without catch crop & 31.3 & 128.3 & 97.6 & 257.2 \\
\hline White mustard & 45.3 & 128.3 & 123.2 & 296.9 \\
\hline Lacy phacelia & 49.3 & 128.3 & 123.2 & 300.8 \\
\hline Faba bean + spring vetch & 78.1 & 128.3 & 109.3 & 315.7 \\
\hline
\end{tabular}

The data contained in Table 5 demonstrate that the differences in the direct costs incurred on spring wheat production were primarily due to the higher expenditures made to purchase the seed material for the catch crops (the highest cost related to legume seeds, while the lowest one to white mustard) and also resulted from the initial rate of mineral $\mathrm{N}$ fertilisation applied in the cultivation of the catch crops. Given that, the cultivation of spring wheat without catch cropping proved to be the least cost-consuming.

The stubble crops had a significant effect on the spring wheat grain yield, which was reflected in the value of the grain yield harvested (Table 6). Moreover, the economic profitability of the monoculture cultivation of spring wheat with an in-between crop in the form of stubble crops increased due to direct payments for cover cropping from the EU funds under the RDP. In consequence, the highest gross margin $\left(657.1 € \mathrm{ha}^{-1}\right)$ was obtained 
in the treatment with the white mustard catch crop, followed by that with the lacy phacelia catch crop $\left(622.7 € \mathrm{ha}^{-1}\right)$. Growing the legume mixture produced a smaller economic effect, but it was noticeably larger compared to the control treatment (without catch crops). To sum up, it should be concluded that the introduction of catch cropping to the spring wheat monoculture resulted in obtaining an increase in the obtained gross margin by $130.1 € \mathrm{ha}^{-1}$ (legume mixture) - $182.7 € \mathrm{ha}^{-1}$ (white mustard) relative to the "pure monoculture" (without a catch crop).

Table 6

Output and gross margin obtained from the monoculture cultivation of spring wheat depending on the catch crop $\left[€ \mathrm{ha}^{-1}\right]$ - on average over the study period

\begin{tabular}{|c|c|c|c|}
\hline \multirow{2}{*}{ Specification } & \multicolumn{2}{|c|}{ Output } & \multirow{2}{*}{ Gross margin } \\
\cline { 2 - 3 } & Grain yield value & RDP payments & 474.4 \\
\hline Without catch crop & 474.4 & - & 657.1 \\
\hline White mustard & 554.4 & 102.7 & 622.7 \\
\hline Lacy phacelia & 520.0 & 102.7 & 604.5 \\
\hline Faba bean + spring vetch & 501.8 & 102.7 & \multirow{2}{*}{} \\
\hline
\end{tabular}

The profitability of production is associated with its intensity that ensures to the producer sufficient grain yield, which determines obtaining a gross margin. The economic evaluation may only include direct costs, being based on an incomplete simplified calculation, and in consequence the gross margin is calculated as the difference between the value of grain harvested per ha and the direct costs of industrial production means. In the opinion of many authors [18-23], intensification of inputs on cereal cropping does not cause a significant increase and thus the gross margin is the highest when economical or moderately intensive technology is used. In their study. Kwiatkowski [6] noted that the use of catch cropping did not distinctly improve the economic effect of monoculture cultivation of spring barley. Nonetheless, a white mustard catch crop, owing to the low cost of the seed material and its greater impact on barley yields, increased the gross margin value by about $15 \%$. On the other hand, a mixed legume stubble crop and an undersown crop (Westerwolds ryegrass) slightly reduced it due to the high cost of seeds and their lower effect on barley yields.

Irrespective of the results of the present study presented above and the views of other authors, it should be noted that technology intensity and production efficiency are affected by a number of natural factors, as well as economic and organizational factors that determine the level of yields and gross margin [24]. Catch cropping greatly contributes to improved productivity of main yield crops $[3,25]$ and in consequence to a better economic result of crop production.

The final stage of the analysis of the productivity of spring wheat grown under several years of monoculture was the energy evaluation of the individual tillage systems and stand regeneration through cultivation of catch crops. The labour consumption of spring wheat production was more dependent on the tillage system than on catch cropping (Table 7). Under conventional tillage conditions, the labour inputs were higher, on average by $15 \%$ for human labour and $20 \%$ for the machinery inputs, than those under no-tillage (Table 8). Conventional tillage caused a higher (on average by $36 \%$ ) consumption of fuel compared with no-tillage (Table 9). A higher consumption of fuel (by $25 \%$ ) was also associated with the sowing and harvesting of the catch crops. 
Labour inputs on spring wheat production [man hours ha $\left.{ }^{-1}\right]$ - on average over the study period

\begin{tabular}{|c|c|}
\hline \multicolumn{2}{|c|}{ Specification } \\
\hline Tillage system & Mean \\
\hline Conventional & 27.6 \\
Conservation (no-tillage) & 23.4 \\
\hline \multicolumn{2}{|c|}{ Catch crops in monoculture } \\
\hline Without catch crop & 27.6 \\
White mustard & 34.0 \\
Lacy phacelia & 34.0 \\
Faba bean + spring vetch & 34.0 \\
\hline
\end{tabular}

Table 8

Machinery inputs on spring wheat production [tractor hours $\mathrm{ha}^{-1}$ ] - on average over the study period

\begin{tabular}{|c|c|}
\hline \multicolumn{2}{|c|}{ Specification } \\
\hline Tillage system & Mean \\
\hline Conventional & 19.3 \\
Conservation (no-tillage) & 15.4 \\
\hline \multicolumn{2}{|c|}{ Catch crops in monoculture } \\
\hline Without catch crop & 27.6 \\
White mustard & 34.0 \\
Lacy phacelia & 34.0 \\
Faba bean + spring vetch & 34.0 \\
\hline
\end{tabular}

Table 9 Consumption of fuel $\left[\mathrm{L} \mathrm{ha}^{-1}\right]$ by tractors and the combined harvester for spring wheat production - on average over the study period

\begin{tabular}{|c|c|}
\hline \multicolumn{2}{|c|}{ Specification } \\
\hline Tillage system & Mean \\
\hline Conventional & 158.2 \\
Conservation (no-tillage) & 101.4 \\
\hline \multicolumn{2}{|c|}{ Catch crops in monoculture } \\
\hline Without catch crop & 121.9 \\
White mustard & 162.4 \\
Lacy phacelia & 162.4 \\
Faba bean + spring vetch & 162.4 \\
\hline
\end{tabular}

Energy value [GJ ha ${ }^{-1}$ ] of grain yield of spring wheat - on average over the study period

Table 10

\begin{tabular}{|c|c|}
\hline \multicolumn{2}{|c|}{ Specification } \\
\hline Tillage system & Mean \\
\hline Conventional & 84.8 \\
Conservation (no-tillage) & 80.0 \\
\hline \multicolumn{2}{|c|}{ Catch crops in monoculture } \\
\hline Without catch crop & 76.1 \\
White mustard & 89.0 \\
Lacy phacelia & 84.1 \\
Faba bean + spring vetch & 80.6 \\
\hline
\end{tabular}

The energy value of output is a derivative of the grain yield of spring wheat (Table 1). The differences in the energy value are presented in Table 10. This comparison shows that a higher energy value of grain yield was obtained by using conventional tillage, relative to no-tillage. Regardless of the tillage system, the introduction of catch cropping in the spring 
wheat monoculture contributed to an increase in the energy value of grain yield by respectively: $6 \%$ (legume mixture), $10 \%$ (lacy phacelia), and $15 \%$ (white mustard).

The energy inputs on spring wheat production under conventional tillage conditions were higher by nearly $21 \%$ than those under conservation tillage (Table 11). However, catch cropping contributed to an increase in energy inputs by about $20 \%$ in comparison with "pure monoculture" (without a catch crop).

Energy inputs [GJ ha' $\mathrm{ha}^{-1}$ on spring wheat production - on average over the study period

Table 11

\begin{tabular}{|c|c|}
\hline \multicolumn{2}{|c|}{ Specification } \\
\hline Tillage system & Mean \\
\hline Conventional & 21.4 \\
Conservation (no-tillage) & 16.9 \\
\hline \multicolumn{2}{|c|}{ Catch crops in monoculture } \\
\hline Without catch crop & 17.4 \\
White mustard & 21.8 \\
Lacy phacelia & 21.8 \\
Faba bean + spring vetch & 21.8 \\
\hline
\end{tabular}

Table 12

Energy efficiency index of spring wheat production - on average over the study period

\begin{tabular}{|c|c|}
\hline \multicolumn{2}{|c|}{ Specification } \\
\hline Tillage system & Mean \\
\hline Conventional & 3.96 \\
Conservation (no-tillage) & 4.73 \\
\hline \multicolumn{2}{|c|}{ Catch crops in monoculture } \\
\hline Without catch crop & 4.37 \\
White mustard & 4.08 \\
Lacy phacelia & 3.85 \\
Faba bean + spring vetch & 3.69 \\
\hline
\end{tabular}

Based on the energy evaluation, it can be concluded that the efficiency of spring wheat production was dependent on the factors included in the study. Regardless of the catch crops, a more favourable energy efficiency index (4.73) was obtained by using no-tillage, mainly due to the high energy inputs that were generated by the conventional tillage system (Tables 11 and 12). In the opinion of Hansen et al. [14], about 4 energy units in the main yield per one energy input unit should be obtained in crop production under average farming conditions. In the present study, the high energy value of the yield obtained in the conventional tillage treatment did not compensate for the high inputs to produce the main yield (grain). In consequence, the energy efficiency index in this treatment was 3.96.

Irrespective of the tillage system, the energy efficiency index was found to be more favorable for the monoculture cultivation of spring wheat without a catch crop than where the catch crops were grown (Table 12). In spite of the additional energy inputs associated with the cultivation of the white mustard catch crop (treatment B), the energy efficiency index calculated for this treatment was above 4 (4.08). This evidences that despite generating higher energy inputs, growing white mustard as a stubble crop is profitable, due to its positive effect on grain yield and the energy value of output. In the case of the other stubble crops included in this study, the energy efficiency index was less favourable (in particular where the legume mixture was grown as a catch crop). 
To sum up, based on the above analysis regarding the efficiency of spring wheat production under several years of monoculture, it is worth noting that the cultivation of white mustard as a stubble crop can be recommended from the economic and energy points of view. The above-mentioned catch crop contributed to obtaining the highest gross margin on spring wheat production and besides it allowed a favourable energy efficiency index to be achieved. The mixture of legumes (faba bean + spring vetch) proved to be unreliable, since it is characterized by a high price of seeds and exhibits the weakest growth and biomass increase rate, translating into the weakest regeneration effect under spring wheat monoculture. This, in turn, has a direct impact on achieving unfavourable economic and energy efficiency indices.

Nevertheless, the economic and energy evaluation of the tillage systems included in this study is not unambiguous. The simplified economic calculation (gross margin) did not capture the differences between the individual tillage treatments. These differences would probably weigh in favour of conservation tillage if a thorough economic analysis of spring wheat production was performed, include not only the financial expenditures made to purchase the seeds, crop protection products and mineral fertilisers, but also the costs of labour, fuel and depreciation of implements. This thesis is confirmed by the results obtained from the analysis of energy efficiency of spring wheat production which demonstrates that conventional tillage contributes to increased production costs (e.g. fuel inputs are about $30 \%$ higher than for conservation tillage) [21, 26-32]. Therefore, conservation tillage combined with cultivation of white mustard as a catch crop can be tentatively recommended to be applied in agricultural practice.

\section{Conclusion}

The stubble catch crops stimulated the productivity of spring wheat, while the biomass of white mustard ploughed in in autumn had the most beneficial effect.

The conventional tillage system can be recommended only where the cultivated catch crops are left as mulch until the spring period (conservation tillage). However, reduced tillage under "pure monoculture" without a catch crop caused a distinct decrease in the productivity of spring wheat.

Based on the simplified economic calculation (gross margin) for spring wheat production, it can be concluded that it is advisable to introduce a white mustard catch crop as an in-between crop in monoculture. The white mustard catch crop also had a great impact on obtaining a favourable energy effect of the monoculture cultivation of spring wheat.

\section{References}

[1] Hansen EM, Kristensen K, Djurhuus J. Yield parameters as affected by introduction or discontinuation of catch crop use. Agron J. 2000;92:909-14. DOI: 10.2134/agronj2000.925909x.

[2] Brant V, Neckar K, Pivec J, Duchoslav M, Holec J, Fuksa P, Competition of some summer catch crops and volunteer cereals in the areas with limited precipitation. Plant Soil Environ. 2009;55(1):17-24. DOI: 10.17221/378-PSE.

[3] Kwiatkowski CA, Harasim E, Pawłowski L. Can catch crops be an important factor in carbon dioxide sequestration? Int J Cons Sci. 2020;11(4):1005-18. Available from: http://ijcs.ro/public/IJCS-2074_Kwiatkowski.pdf.

[4] Haramoto ER, Gallandt ER. Brassica cover: I. Effects on weed and crop astablishment. Weed Sci. 2005;53(5):695-701. DOI: 10.1614/WS-04-162R.1. 
[5] Harasim E, Antonkiewicz J, Kwiatkowski CA. The effects of catch crops and tillage systems on selected physical properties and enzymatic activity of loess soil in a spring wheat monoculture. Agronomy. 2020;10:334. DOI: 10.3390/agronomy10030334.

[6] Kwiatkowski CA, Harasim E, Wesołowski M. Effects of catch crops and tillage system on weed infestation and health of spring wheat. J Agr Sci Tech. 2016;18:999-1012. Available from: https://jast.modares.ac.ir/article-23-515-en.pdf.

[7] Cantero-Martinez C, Angas P, Lampurlanes J. Growth, yield and water productivity of barley (Hordeum vulgare L.) affected by tillage and $\mathrm{N}$ fertilisation in Mediterranean semiarid, rainfed conditions of Spain. Field Crops Res. 2003;84:341-57. DOI: 10.1016/S0378-4290(03)00101-1

[8] Berner A, Hildermann I, Fliessbach A, Pfiffner L, Niggli U, Mader P. Crop yield and soil fertility response to reduced tillage under organic management. Soil Till Res. 2008;101(1-2):89-96. DOI: 10.1016/j.still.2008.07.012.

[9] Woźniak A, Kwiatkowski CA. Effect of long-term reduced tillage on yield and weeds of spring barley. J Agr Sci Tech. 2012;15:1335-42. Available from: https://jast.modares.ac.ir/article-23-926-en.pdf.

[10] Ozpinar S. Effects of tillage systems on weed population and economics for winter wheat production under the Mediterranean dryland conditions. Soil Till Res. 2006;108:1-15. DOI: 10.1016/j.still.2005.02.024.

[11] Vogeler I, Rogasik J, Funder U, Panten K, Schung E. Effect of tillage systems and P-fertilization on soil physical and chemical properties, crop yield and nutrient uptake. Soil Till Res. 2009;103(1):137-43. DOI: 10.1016/J.STILL.2008.10.004

[12] Kassam A, Friedrich T, Shaxson F, Pretty J. The spread of conservation agriculture: justification, sustainability and uptake. Int J Agricult Sust. 2009;7(4):292-320. DOI: 10.3763/ijas.2009.0477.

[13] Kassam A, Friedrich T, Derpsh R. Conservation agriculture in the $21^{\text {st }}$ century: a paradigm of sustainable agriculture. Materials of European Congress on Conservation Agriculture, Madrid-Spain, October 2010, pp. 19-68. Available from: https://taa.org.uk/wp-content/uploads/2018/10/ Paper5\%20CA_Madrid_final[1].pdf.

[14] Hansen EM, Kristensen K, Djurhuus J. Yield parameters as affected by introduction or discontinuation of catch crop use. Agron J. 2000;92:909-14. DOI: 10.2134/agronj2000.925909x.

[15] Kwiatkowski CA, Harasim E, Haliniarz M, Gawęda D, Misztal-Majewska B, Chojnacka S. Chemical composition of stubble catch crop biomass depending on a crop plant species and tillage system. J Elementology. 2019;24(4):1371-81. DOI: 10.5601/jelem.2019.24.2.1797.

[16] Kraska P. Content of some elements in grain of spring wheat cv. Zebra depending on soil tillage systems and catch crops. J Elementology. 2011;16(3):407-19. DOI: 10.5601/jelem.2011.16.3.06.

[17] Włodek S, Biskupski A, Sekutowski T, Smagacz J. Effects of the long-term application of tillage simplifications on some soil properties and yield of chosen spring plants. Acta Sci Pol Agricultura. 2012;11(2):85-95. Available from: http://old-agricultura.acta.utp.edu.pl/uploads/pliki/11(2)2012_8.pdf.

[18] Kraska P, Andruszczak S, Kwiecińska-Poppe E, Pałys E. The effect of tillage systems and catch crops on the yield, grain quality and health of spring wheat. Acta Sci Pol Agricultura. 2014;13(1):21-38. Available from: http://yadda.icm.edu.pl/yadda/element/bwmeta1.element.agro-1d1407b0-4738-477e-b650-5e8afdea7f86.

[19] Khan S, Khan MA, Latif N. Energy requirements and economic analysis of wheat, rice and barley production in Australia. Plant Soil Environ. 2010;21(1):61-8. Available from: www.se.org.pk.

[20] Skarżyńska A. Cropping intensity vs. profitability of selected plant production activities in Poland. Stud Agric Econ. 2012;114:33. DOI: 10.22004/ag.econ.122446.

[21] Wysokiński M, Klepacki B, Gradziuk P, Golonko M, Gołasa P, Bieńkowska-Gołasa W, et al. Economic and energy efficiency of farms in Poland. Energies. 2021;14:5586. DOI: 10.3390/en14175586.

[22] Nieróbca P, Grabiński J, Szeleźniak E. Influence of production technology intensity of grain species planted in cereal crop rotation on productive and economic effectiveness. Acta Sci Pol Agricultura. 2008;7(3):73-80. Available from: http://yadda.icm.edu.pl/yadda/element/bwmeta1.element.dl-catalog-50d20a52-1c1b-452a8e13-c184ccabaed7.

[23] Bielski S. Economic efficiency of winter triticale grain production. Acta Sci Pol Oecon. 2014;13:18. Available from: http://yadda.icm.edu.pl/yadda/element/bwmeta1.element.agro-6af83edb-f129-4809-bb3219cfa5750976/c/17-23.pdf.

[24] Zargar M, Polityko P, Pakina E, Bayat M, Vandyshev V, Kavhiza N, et al. Productivity, quality and economics of four spring wheat (Triticum aestivum L.) cultivars as affected by three cultivation technologies. Agronomy Res. 2018;16(5). DOI: 10.15159/AR.18.204.

[25] Pawłowski L, Pawłowska M, Kwiatkowski CA, Harasim E. The role of agriculture in climate change mitigation - A Polish example. Energies. 2021;14:3657. DOI: 10.3390/en14123657.

[26] Konieczna A, Roman K, Roman M, Śliwiński D, Roman M. Energy efficiency of maize production technology: Evidence from Polish farms. Energies. 2021;14:170. DOI: 10.3390/en14010170. 
[27] Mao Y, Li N. Suitability of rural living \& work facilities, spatial behavior of farmers and family income. Problemy Ekorozwoju - Problems Sust Development. 2022;17(1):71-83. DOI: 10.35784/pe.2022.1.07.

[28] Cao Y, You J, Shi Y, Hu W. Studies on improving the performance of small and micro enterprises through green innovation. Problemy Ekorozwoju - Problems Sust Development. 2022;17(1):151-61. DOI: 10.35784/pe.2022.1.14.

[29] Ospanova A, Popovychenko I, Chuprina E. Green economy - vector of sustainable development. Problemy Ekorozwoju - Problems Sust Development. 2022;17(1):171-81. DOI: 10.35784/pe.2022.1.16.

[30] Morkunas M, Žičkienė A, Baležentis T, Volkov A, Štreimikienė D, Ribašauskienė E. Challenges for improving agricultural resilience in the context of sustainability and rural development. Problemy Ekorozwoju - Problems Sust Development. 2022;17(1):182-95. DOI: 10.35784/pe.2022.1.17.

[31] Thai Hung N. Time-frequency co-movements between biomass energy consumption and human development in brics countries. Problemy Ekorozwoju - Problems Sust Development. 2022;17(1):196-210. DOI: $10.35784 /$ pe.2022.1.18.

[32] Ochuba O, Ahuru RR, Ashraf J. Trade openness, foreign direct investment and sustainable agriculture in Africa. Problemy Ekorozwoju - Problems Sust Development. 2022;17(1):246-55. DOI: 10.35784/pe.2022.1.22. 